\title{
変形性膝関節症に対する高位脛骨骨切り術の長期成績
}

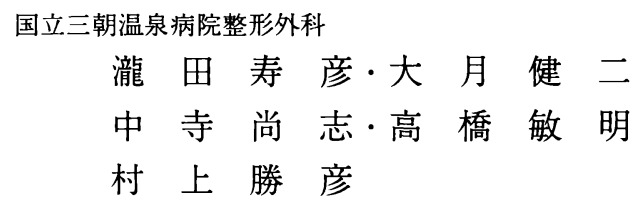

\section{A Long Term Follow-Up Study of High Tibial Osteotomy in Medial Osteoarthritis of the Knee}

by

Toshihiko Takita, Kenji Otsuki, Takashi Nakadera, Toshiaki Takahashi and Katsuhiko Murakami

Department of Orthopedic Surgery, Misasa Onsen National Hospital

Fifty-seven knees in 41 patients with medial osteoarthritis treated by high tibial osteotomy (HTO) were clinically reviewed. Average age of patients was 66.7 years. Patients were evaluated from 5 to 15 years postoperatively (mean, 8.5 years). Clinical results were satisfactory in $85 \%$ of the knees at the five year follow-up evaluation and in $81 \%$ at last follow-up evaluation. Two knees required TKA after 11 and 12 years. The femorotibial angle (FTA) at one year and last follow-up significantly correlated with the last clinical score and improvement score. FTA one year after surgery was one of the main factors that influenced long term results. The mean FTA immediately after surgery was $168.4^{\circ}$ in patients who had an excellent improvement score. The change of FTA after surgery was minimum in patients who were corrected to nearly $170^{\circ}$. Clinical results were satisfactory even in the elderly over 70 years old.

Key words : High tibial osteotomy (高位脛骨骨切り術), Medial osteoarthritis of the knee (内側型変形性膝関節症), Long term results（長期成績）

目的

内側型変形性膝関節症に対して高位脛骨骨切り術 （以下 HTO と略す）を行い, 術後 5 年以上経過した 症例の術後成績と長期成績に影響を与える因子につい て検討したので報告する。

\section{対 象, 方 法}

症例は 41 例 57 膝（男 6 例，女 35 例）で, 手術時 年齢は $51 \sim 81$ 歳 (平均 66.3 歳)，追跡期間は $5 \sim 15$ 年 (平均 8.5 年) である。手術方法は楔状骨切りを 45 例，ドーム骨切りを 13 例に行った。 固定はネジ付 き鋼線による tension band wiring 法で, 術後はギ
ブス固定を 6 週間併用した. 荷重時期は 4 週より部分 荷重を行い，8週で全荷重歩行とした。臨床成績は三 大学膝関節機能評価を用いた。総合点で 90 点以上を good, 89 点から 75 点までを fair, 74 点以下を poor と定義した。レ線学的評価には立位膝正面単純 X 線 像における大腿骨脛骨角（FTA），Mikulicz 荷重線 の変化を計測し, OA stage の判定には北大分類を用 いた。

結

果

\section{臨床成績}

膝関節機能評価点は総合点で術前平均 $60.3 \pm 10.0$ 点が, 5 年経過時 $85.2 \pm 9.9$ 点と改善し, 最終調查時 
でも $83.9 \pm 13.5$ 点と維持されていた（図 1).70 歳以 上の症例でも術前 59.9 点が, 最終調査時 83.5 点と改 善が得られた。疼痛点で $12.4 \pm 5.4$ が五年後 $27.0 \pm$ 6.6 , 最終調查時 $25.6 \pm 8.1$ 亿と改善し, 歩行能力 は術前 $11.2 \pm 3.3$ であったものが，五年後を $15.0 \pm$ 3.8 , 最終調査時は $15.3 \pm 4.0$ と改善が認められた. 術前 fair $8 \%$, poor $92 \%$ が, 五年後は $\operatorname{good} 39 \%$, fair $46 \%$, poor $15 \%$ と改善し, 最終調查時 good $42 \%$, fair $39 \%$, poor $19 \%$ とほほ維持されていた. 膝関節可動域は術前は伸展 $-5.6 \pm 6.8^{\circ}$, 屈曲 $133.3 \pm$ $14.8^{\circ}$ であったが, 調査時では伸展 $-2.6 \pm 4.7^{\circ}$, 屈曲 $127.8 \pm 17.4^{\circ}$ であり，屈曲角度はやや減少していた

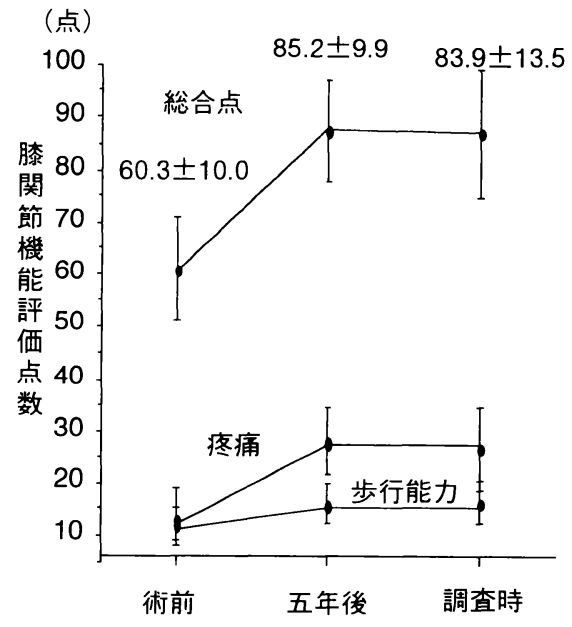

図 1 膝関節機能評価点数の変化

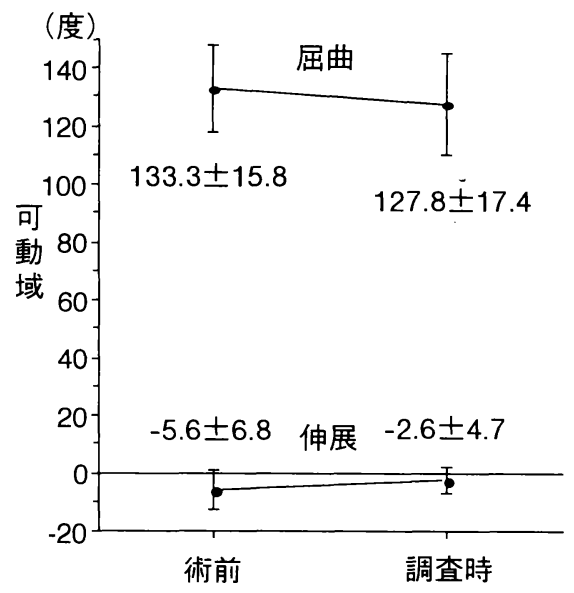

図 2 可動域の変化
（図 2)，合併症は腓骨神経麻瘏が 3 例あり，1 例は神 経剥離術を，他は保存的治療にて治瘾した，術後の拘 縮が 1 例あり，マニプレーションにて改善した。骨瘉 合の遷延は 3 例，偽関節は 1 例であった，TKA へ移 行した症例は 2 例であり，それぞれ術後 11 年と 12 年 であった。

\section{$\mathrm{X}$ 線学的評価}

立位 FTA は術前平均 $185.9 \pm 5.2^{\circ}$ が術後 $171.0 \pm$ $5.0^{\circ}$ に矯正され，5年経過時では $171.7 \pm 6.5^{\circ}$ と変化 ないが，最終調查時では $172.4 \pm 6.0^{\circ}$ となっていた (図 3). 内外反への変動についてみると, 術後半年 一年が $0.23 \pm 2.8^{\circ}$ ，一年から五年が $0.3 \pm 3.6^{\circ}$ ，五年

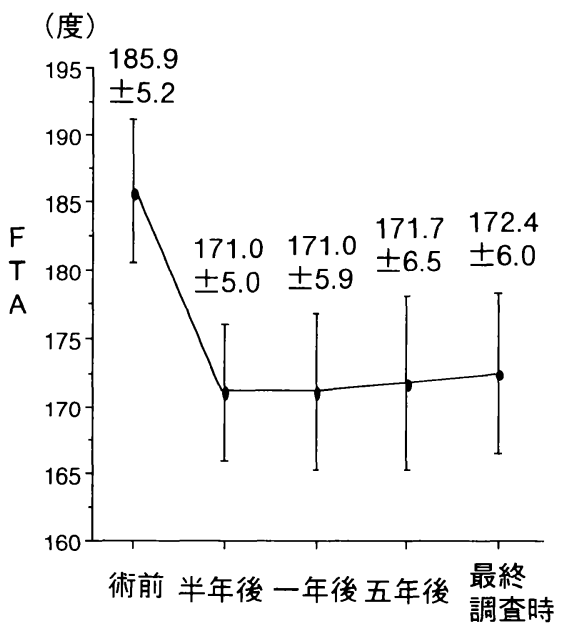

図 3 FTA の経年変化

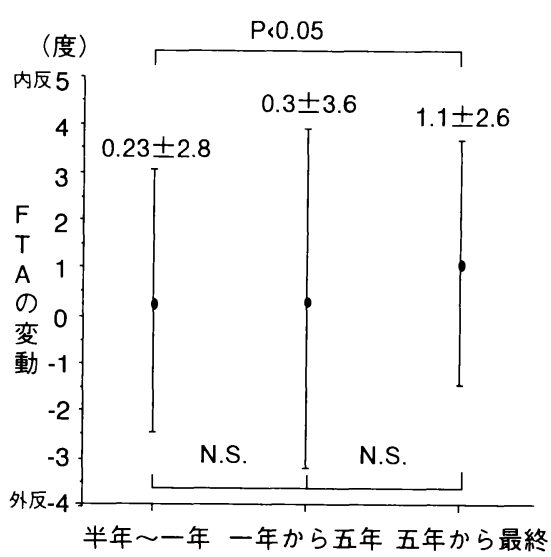

図 4 術後FTAの変動 
から最終が $1.1 \pm 2.6^{\circ}$ であり，術後半年〜一年と五年 から最終との間に有意差を認めた（図 4)。術後 1 年 時 FTA と術後半年〜一年の FTA の内外反への変動 との間には強い相関が見られた。術後一年時 FTA が 170 度付近が最も変動が少なかった（図 5)。OA stage は術前は stage II $17 \%$ ， III $33 \% ，$ IV $43 \%$ ， V $6 \%$ が, 最終調査時には stage II $15 \%$, III $63 \%$, IV 20\%, V $2 \%$ と改善を認めた（表 1).

長期成績に影響を当たる因子の検討

表 1 術前及び最終調査時の OA stage

\begin{tabular}{lc|c|c|c|c}
\hline \hline & II & III & IV & V \\
\hline 術 & 前 & $8(17 \%)$ & $15(33 \%)$ & $20(43 \%)$ & $3(6 \%)$ \\
\hline \multicolumn{2}{l|}{ 最終調査時 } & $7(15 \%)$ & $29(63 \%)$ & $9(20 \%)$ & $1(2 \%)$ \\
\hline
\end{tabular}

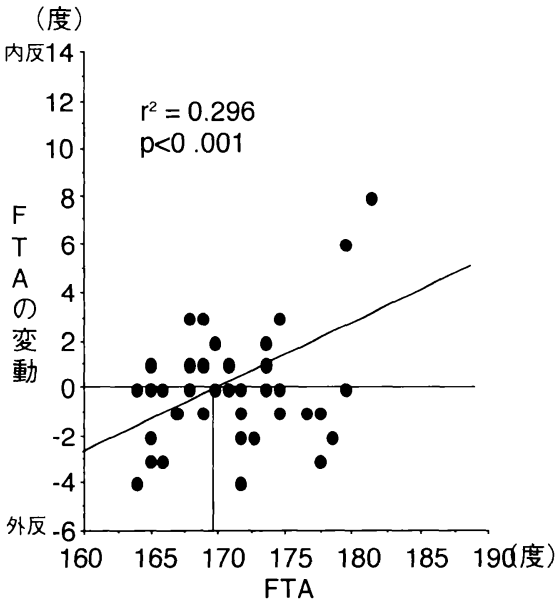

図 5 一年時 FTA と術後〜一年時の FTA の変動 との関係

（点）

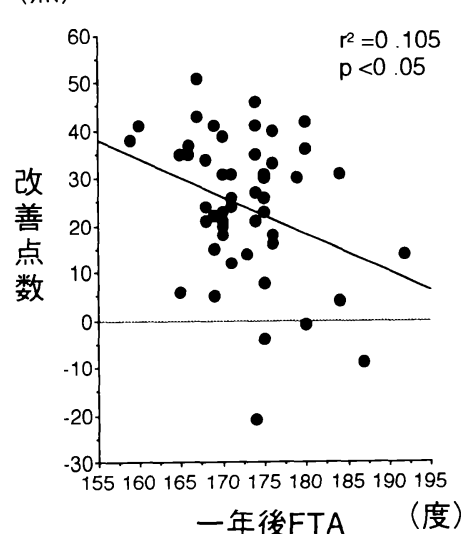

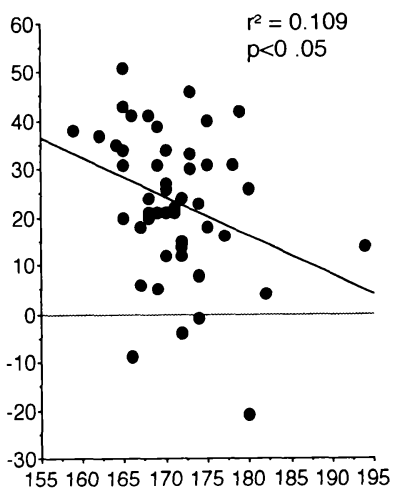

最終調查時FTA

(度)

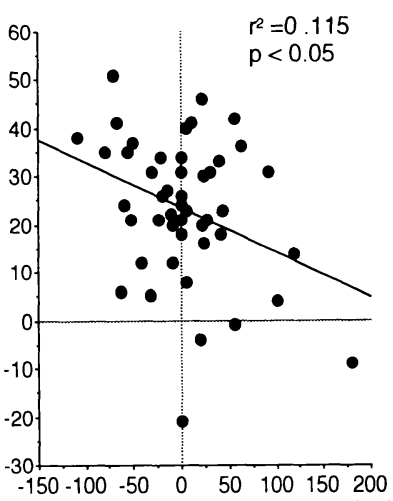
Mikulicz 荷重線（\%)

図6 FTA, Miklicz 荷重線と改善点数の関俰

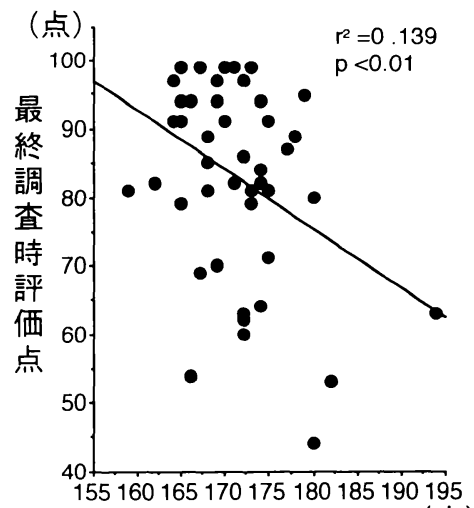

一年後FTA

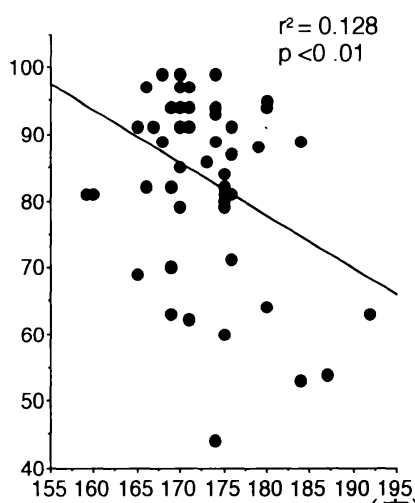

最終調查時FTA

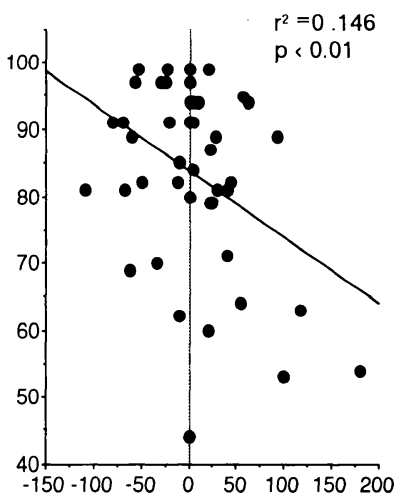

Mikulicz 荷重線（\%）

図 7 FTA, Miklicz 荷重線と最終調査時評価点の関係 


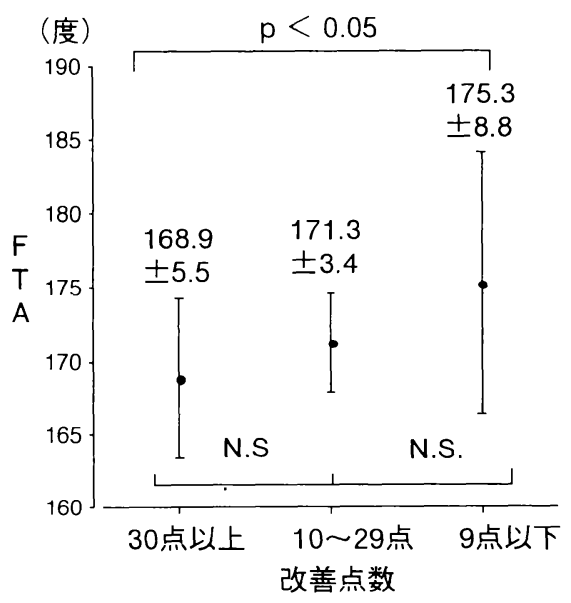

図8 1 年時 FTA と改善点数各群間の比較

術後 1 年時 FTA, 最終調查時 FTA, Mikulicz 荷 重線と総合評価点の間には有意な相関が認められた (図 6).また膝関節機能評価点数の最終時点数から術 前点数を差し引いたもの改善点数をすると, 術後 1 年 時 FTA, 最終調查時 FTA, Mikulicz 荷重線と改善 点数の間には有意な相関関係が認められた（図 7). すなわち術後 1 年時, 最終調査時 FTA が低いものほ ど改善点数が高い傾向であった. 改善点数が 30 点以 上の群, 10 から 29 点の群, 9 点以下の群の術後 1 年 時 FTA を比較すると 30 点以上の群は 9 点以下の群 に比し 1 年時 FTA が有意に低かった（図 8). 改善 点数が 30 点以上の群の術直後の平均臥位 FTA は $168.4 \pm 6.1^{\circ}$ であった。 術前 stage, 手術時年齢, 骨 切り及び固定方法は臨床成績との間に有意な相関は認 めなかった。

考

察

臨床成績は五年経過時 $85 \%$ が good または fair で あり, 平均 8.5 年の最終調查時でも $81 \%$ が $\operatorname{good} ま$ たはfair とほぼ維持されていた。長期成績に影響を 与える因子を検討すると最も長期成績と相関したのは FTA であった．特に安田ら ${ }^{2 / 3)} も$ 報告しているように 術後 1 年の FTA は長期成績を左右する因子として重 要と考えられた. 改善点数が 30 点以上の群の術直後 の平均臥位 FTA は $168.4 \pm 6.1$ であり, 術後一年時
立位 FTA が 170 度付近が最も変動が少なかったこと から, 至適 FTA は $168^{\circ} \sim 170^{\circ}$ と考えた. 術前 stage, 手術時年齢, 骨切り及び固定方法は臨床成績との間に 有意な相関は認めなかった。特に安田ら ${ }^{23)}$ は OAstage IVにHTOの適応の限界があると報告した が, 当院の症例では stage IV の改善率が最も高かっ た。また手術時年齢に関しても，今回の症例で 70 歳 以上が 18 例含まれていたが, 最終調查時の平均総合 点は 83.5 点であり, 69 歳以下の症例と比較してその 長期成績に有意な差はなかった. Insall ら ${ }^{11}$ は 60 藏 以上の HTO の臨床成績は矯正角度の如何に関わらず 不良であったと報告した．今回の我々の内側型変形性 膝関節症に対する HTO は 70 墄以上であってもその 長期成績は良好であった。

$$
\text { ま と め }
$$

(1)変形性膝関節症に対し高位脛骨骨切り術を行い, 5 年以上経過した 57 膝の術後長期成績を報告した.

(2)臨床成績を良好であり, 術後平均 8.5 年の最終調 査時でもほほ満足すべき結果であった。

(3)最終調查時の総合評価点及び改善点数と術後 1 年 時, 最終調查時 FTA, 最終調査時 Mikulicz 荷重線 の位置との間には有意な負の相関を認めた。

(4)改善点数が 30 点以上の群の術直後の平均臥位 FTA $168.4 \pm 6.1^{\circ}$ であり，また術後 1 年時立位 FTA が 170 度の症例が術後 FTA の内外反への変動 が最も少なかった。

(5)術前 stage, 手術時年齢, 骨切り及び固定方法は 臨床成績との間に有意な相関は認めなかった。特に 70 歳以上の症例においても長期成績は良好であった.

\section{参 考 文 献}

1) Insall, J., et al.: High tibial osteotomy. A 5-year evaluation. J. Bone Joint Surg., 56-A : 1397, 1979.

2) Kazunori, Y., et al.: A Ten-to 15-year follow-up observation of high tibial osteotomy in medial compartment osteoarthrosis. Clin. Orthop., 282 : 185-195, 1990.

3）安田和則ら：内側型変形性膝関節症に対する高位脛骨 骨切り術の長期成績一術後 10 年以上経過例の検討一. 臨 床整形外科, 25(1) : 3-10, 1990 . 